\title{
The President's Domestic Agenda, Divided Government, and the Relationship to the Public Agenda
}

\author{
Jeff Cummins
}

Initial research on presidential agenda-setting suggested the president can focus the public's attention on certain policy issues, while subsequent research has concluded the president may be more limited in his agenda-setting capacity and that a reciprocal relationship may exist between the president and the public. The purpose of this paper is to address this research in three ways. First, I update and extend the time period studied in the earlier research, 1953-1989, by including an additional 11 years of data. Second, I explore three substantive policy areas within domestic policy, crime, education, and health and social welfare, which were previously not examined, to determine the reciprocal nature of the relationship and whether the president's influence has diminished. Third, I investigate a factor in presidential agenda-setting that has heretofore been ignored in the literature-divided government. Time series analysis of annual data reveal that a reciprocal relationship exists, the president has significant influence over the public agenda in all three areas, and that divided government makes the president's agenda-setting job more difficult.

There is little disagreement in the literature on agenda setting that the institution that controls the agenda wields unmatched power in the legislative process (Baumgartner and Jones 1993; Cobb and Elder 1972; Kingdon 1995). However, a less settled question remains over which institution, Congress or the president, controls the agenda and when. To address this, scholars have dedicated their efforts to disentangling the relationships between the agendas of the president, Congress, the media, and the public (Cohen 1995; Edwards and Barrett 2000; Edwards and Woods 1999; Eshbaugh-Soha and Peake 2004, 2005; Flemming, Wood, and Bohte 1999; Grusczynski 2004; Hill 1998; Young and Perkins 2005). The assumption behind this work is that the institution that can influence the agendas of others is likely to control the legislative agenda, which will, in turn, translate into a higher level of policy success.

One strand of this agenda research looks at the linkages between the policy priorities of the public and the president. Jeffrey Cohen's (1997) work highlights the impact of the president's rhetoric on the public agenda and sets the stage for much of the subsequent scholarship. Examining the time period from 1953-1989, he explored whether presidential mentions of

Author's Note: A previous version of this paper was delivered at the 2005 Annual Meeting of the American Political Science Association. The author would like to thank Susan Webb Hammond and Lance T. LeLoup for their comments on a previous version of this paper.

JEFF CUMMINS is assistant professor of political science at California State University, Fresno.

The American Review of Politics, Vol. 27, Winter, 2006: 269-294

(c)2006 The American Review of Politics 
different policy areas in State of the Union Addresses (SUA) influence whether the public regards these same areas as important. He finds that the president can set the public's agenda on issues dealing with the economy, civil rights, and foreign policy; however, there is no significant relationship in the general area of domestic policy.

Since these initial findings, subsequent research has raised a number of questions about the link between presidential speeches and the public. One question concerns whether the relationship between presidential and public attention to issues is reciprocal. In a validation and extension of Cohen's research, Hill (1998) explored this possibility and demonstrates that the influence is reciprocal on foreign and economic policy, but not on civil rights. Recent research has also questioned whether the president's influence over the public has weakened in the last few decades. Young and Perkins (2005), focusing exclusively on the president's rhetorical impact on the public, show that declining broadcast viewership may be one reason for the president's diminishing role in public agenda-setting.

This paper builds off of these earlier works by examining the relationship between the president's domestic agenda and the public agenda in several ways. First, similar to Young and Perkins (2005), I extend the time period studied to include the Bush Sr. and Clinton administrations, which adds an additional 11 years of data. The extension of the time period studied is important because it accounts for much of the decline in the viewership of broadcast television. Second, I further examine the direction of influence between the president and the public in domestic policy. Besides civil rights and the economy, previous scholarship has not explored other substantive areas within domestic policy. Thus, this paper focuses on three areas of domestic policy, crime, education and health and social welfare, not previously examined. ${ }^{1}$ Lastly, I investigate a potential factor in the decline of the president's agenda-setting influence that has heretofore been neglecteddivided government. Divided government is potentially significant because a competing agenda from the opposition party is likely to dilute the president's influence over the public agenda. In addition, some of the contradictory findings regarding the president's influence may, in part, be due to divided government since several of the studies investigate periods dominated by its presence (Edwards and Wood 1999; Eshbaugh-Soha and Peake 2005; Wood and Peake 1998).

The implications of this research are important for three reasons. First, the literature on the pathways of influence between presidential speeches and the public is unclear. ${ }^{2}$ There is some evidence that a reciprocal relationship exists in foreign and economic policy (Hill 1998), but the evidence in domestic policy only points to a one-way path from the president to the public (Cohen 1995; Hill 1998). Further analysis may extend the reciprocal 
nature of the president-public link to the domestic realm. Second, since every president inevitably embarks on a speaking tour to promote his favorite initiatives, and evidence is accumulating that this tactic may be ineffective, it suggests presidents may be wasting precious time and resources on a method that is fruitless.

If presidents cannot transform public opinion and through such changes alter the political landscape, then it follows that we should invest less in evaluating their public leadership skills and in attributing their failure to lead the public to their rhetorical or public relations deficiencies (Edwards 2003, 23).

Third, recent findings by Canes-Wrone and de Marchi (2002) indicate that the president's legislative success may depend on public issue salience and his approval ratings. If it can be further demonstrated that the president is able to draw public attention to his agenda priorities, it may illustrate how the president is more in command of his legislative fortunes than previously thought (Bond and Fleisher 1990).

To examine the president-public link, I empirically test models in three policy areas from 1954-2000. Before discussing the theory and hypotheses for the empirical models that follow, it is necessary to clarify why some of the scholarship in this area seems to arrive at mixed results. As such, previous findings regarding the relationship between the agendas of the president and public seem to hinge on several methodological factors: (1) measurement of the president's agenda; (2) measurement of the public agenda; and (3) the types of issues explored. I review each of these in turn and their bearing on the present analysis before proceeding to the theory and hypotheses.

\section{Measuring the President's Agenda}

Scholars have attempted to measure the president's agenda in a number of ways. In Cohen's original work (1995), and the replications by Hill (1998) and Young and Perkins (2005), the president's rhetorical attention to different policy areas in the SUA served as the president's agenda. Since this national speech was typically viewed by scholars and the Washington community as the vehicle for the president's annual agenda (Light 1991), it represents a good approximation of the president's priorities. However, subsequent scholarship took issue with this measure and viewed the agenda as much broader in scope. ". . . These annual speeches may give an incomplete image of attention as it changes due to events and shifting circumstances during the year" (Edwards and Wood 1999, 330). While a valid point, this argument probably applies more in the area of foreign policy where the president is often responding to crisis events, which is indeed 
what Edwards and Wood (1999) found. Instead of employing one annual speech, Edwards and Wood and others (Eshbaugh-Soha and Peake 2004, 2005; Wood and Peake 1998) include all spoken and written messages by the president in their measure of the agenda. These messages are readily accessible to researchers through the Public Papers of the President series. But, as Eshbaugh-Soha and Peake (2005) acknowledge, this broader measure may discount the president's influence over the agenda:

The bulk of scholarship that rejects the president as the dominate actor in agenda-setting focuses on all presidential speeches and does not treat speeches with national audiences differently. Doing so has possibly negated the distinct impact the nationally televised address may have on the president's agenda-setting success (129).

Hence, in investigating the president's relationship with the public, it is important not to ignore the impact of this measure. This paper's findings tend to reinforce this notion. In investigating the president's agenda-setting prowess, it is also crucial to remember, in the present case, whom the president is trying to influence. Some of these previous studies tend to equate measures of media attention to issues with public attention to issues, which may distort the findings as well (this will be discussed further below). However, if we are concerned with the mass public's attention to the president's agenda, it seems more likely that one major speech, such as the SUA, may resonate more with the public than other smaller venues. The more indiscriminate measure of the agenda that includes all communications, both spoken and written, assumes the same level of importance for each vehicle and that the mass public is also likely to be exposed to these outlets. Not only does research indicate that there is a shrinking national audience for televised presidential speeches (Baum and Kernell 1999), it also shows that if a speech is likely to penetrate the public, it is most often the SUA. Thus, for purposes of investigating whether the president can impact the mass public, it seems that one major speech may be more appropriate. This argument, however, does not mean that the indiscriminate measure may be more valid for a study that looks at the president's impact on the media. After all, the media is more likely to follow these additional outlets for presidential communications. With this in mind, I use State of the Union Addresses as the measure of the president's agenda in this case because the public is more likely to view these speeches. ${ }^{3}$

\section{Measuring the Public Agenda}

Just as a positive relationship between the president and the public's agenda may depend on the measure of the president's agenda, the same is 
true for the measurement of the public's agenda. Previous research diverges in two directions from Cohen's (1995) original method when measuring the public agenda. The first direction is best exemplified in Edward's (2003) work where he uses changes in approval ratings to signify whether the president has been successful at moving public opinion. ${ }^{4}$ Initial research along this line of inquiry found that presidents could increase their approval ratings through the use of speeches and other public appearances (Brace and Hinckley 1992; Ragsdale 1984). However, Edwards contradicts these earlier findings and concludes that presidents are fairly limited in their ability to positively impact approval ratings. "Although sometimes they (presidents) are able to maintain public support for themselves and their policies, presidents typically do not succeed in their efforts to change public opinion" (Edwards 2003, 241). While Edwards (2003) suggests the president's influence over public opinion may be fleeting, one shortcoming of his findings is the absence of statistical controls on the results, which calls into question the validity of the findings.

Although approval ratings indicate the public's overall level of satisfaction with the president, they are insufficient for our purposes here. Aside from measures of overall domestic and foreign policy approval, approval ratings do not indicate support for specific items on the president's agenda as public issue salience might. Some citizens may like the president's education priorities, but not his initiatives on the economy, which would be masked in the use of approval ratings. ${ }^{5}$ For this reason, I do not employ approval ratings as a measure of the public's response to the president's agenda.

The second direction that researchers have ventured in their measures of the public agenda is using media attention to different issues in place of the public's attention (Edwards and Wood 1999; Eshbaugh-Soha and Peake 2004, 2005; Wood and Peake 1998). The rationale behind this substitution is based on empirical work that shows the high correlation between the agendas of the media and the public (Iyengar and Kinder 1983: McCombs and Shaw 1993). Typically, scholars have counted the number of stories in major newspapers, such as the New York Times, or the number of nightly news stories on the major public broadcast channels as a proxy of the media's attention. What makes these data particularly attractive is that they can be measured in weekly time series to enlarge the dataset whereas public opinion polls are more limited in nature. However, while these media measures may correlate fairly well with public attention, they still represent an indirect measure of the public's agenda. Additionally, Congress members are ultimately more concerned with public attention to issues rather than the media's, especially when it comes to reelection. Moreover, the research that establishes a link between public issue salience and Congressional voting 
patterns employs public opinion measures rather than media measures (Bartels 1991; Miller and Stokes 1963).

Given these alternatives, I chose the public's designation of the most important problem as a measure of the public's agenda. This is because it is the most direct measure of public priorities and is available annually over the time period examined. As with any measure, it has its shortcomings as well. Public opinion polls are taken relatively infrequently, particularly in the earlier years of this study, but with enough frequency to evaluate the dynamics between the president and the public. Additionally, the time elapsed between the SUA and the public opinion poll varies each year due to the fact that the polls are conducted periodically and the date of the president's speech changes each year.

\section{Types of Issues}

One last factor also seems to play a major role in examinations of the president's impact on the public agenda. Researchers have arrived at different findings depending on whether one looks at foreign policy, domestic policy, or substantive areas within each. With regard to foreign policy, some earlier studies found that the president mainly reacts to foreign policy issues, rather than the president leading them (Edwards and Woods 1999; Wood and Peake 1998). "Presidential agenda-setting authority is further limited over foreign policy, where presidents have been primarily responsive to media attention and international events involving the major national security policy issues of the 1980s and 1990s" (Eshbaugh-Soha and Peake 2005, 127). However, Peake (2001) challenges these findings by suggesting that the president may have more substantial influence over media and congressional attention to some foreign policy issues that are less salient. As Peake $(2001,84)$ notes, "In order to be successful, presidents must pick and choose their issues carefully, even in foreign policy." In addition to Peake (2001), Hill's (1998) study revealed a reciprocal relationship between the president and the public in this area. While foreign policy is not examined in this study, the evidence suggests the relationship between the president and public may be sensitive to the specific issues investigated. Therefore, extending the analysis to previously unexplored issues should further shed light on the dynamics of this link.

In the domestic policy realm, researchers find a more prominent role for the president in agenda-setting and more instances of a reciprocal relationship than in foreign policy. For instance, Cohen (1995) and Hill (1998) find that the president can direct public attention to civil rights issues, while Eshbaugh-Soha and Peake (2004) arrive at similar findings in their analysis of the president's impact on media attention from 1950-1998. Additionally, 
Eshbaugh-Soha and Peake (2004) argue that the influence in this area flows both ways between the president and the media. In a similar vein, Edwards and Woods (1999) explore crime, health care, and education, the same three examined in this study, and uncover evidence for one and two-way relationships in the president-media link. In education, the influence is reciprocal, while the president sets the media's agenda in health care and vice versa in crime.

As mentioned previously, one of the purposes of this work is to explore three domestic areas not previously examined by scholars. Although Cohen (1997) investigated a broad domestic policy category, he did not disaggregate this category to look at substantive issues within it due to the low variation in the data. Further, the results in domestic policy revealed a counterintuitive inverse relationship between the president and the public. That is, as the public became more concerned with domestic policy issues, the president afforded less attention to this area. In their extensions of Cohen's work, neither Hill (1998) nor Young and Perkins (2005) reexamined the domestic policy category.

Given the plethora of findings across both foreign and domestic policy, an examination of the three issues in this study is warranted for several reasons. First, no study of the president-public link has looked at what might be considered three of the most important substantive issues within domestic policy, aside from the economy. ${ }^{6}$ Thus, if we are to draw conclusions about the president-public link in domestic policy, it seems appropriate to place these non-economic issues under the microscope. Second, one argument made in this article is that measurement of the relevant variables matters in evaluating the president's impact over the public. Since Edwards and Wood (1999) assessed similar domestic issues in their study using different measures of the president's agenda and substituted media attention for public attention, it provides a relatively good comparison of how different approaches may yield a stronger connection between the president and the public. Lastly, this study also introduces divided government as a potential explanation for the president's apparent declining influence over the public. Unlike foreign policy, where bipartisanship is more common, this study's policy areas represent issues where the outparty is likely to have a competing agenda, which provides a good test of whether divided government is one culprit in the president's weaker agenda-setting role.

\section{Theory and Hypotheses}

A review of the literature on presidential agenda-setting provides the foundation for several hypotheses regarding the president-public link. The first hypothesis concerns the direction of influence between the president 
and the public. Previous studies suggest the influence may flow in one direction or in both. I posit it is likely to be the latter. The first and second hypotheses incorporate this assumption. Since the president is considered a representative of the entire nation and his reelection depends upon pubic sentiment, the president has an incentive to respond to the public's priorities. "It has been widely observed that presidents since Franklin Roosevelt have been highly attentive - and often highly responsive - to public opinion" (Hill 1998, 1329). Despite the president's reluctance to admit use of such polls, this information is readily available to the president through his cadre of advisors. While a president may resist public opinion in specific circumstances, the president should reflect what the public wants more often than not. Research on the influence of public opinion on presidential policy decisions tends to reinforce this assumption (Canes-Wrone and Schotts 2004; Stimson, MacKuen, and Erikson 1995), while a recent study by Yates and Whitford (2005) demonstrates public opinion's impact on the president's rhetorical attention to crime. Thus, a proper theoretical perspective should take into account the potential influence of public opinion on the president's agenda.

$H_{1}$ (Presidential Agenda Hypothesis): As public attention to a given policy area increases, the president's attention in State of the Union Addresses should also increase.

Although several studies indicate that the president's influence over the public is declining, presidents still retain several advantages that allow them to affect public opinion. As a single actor in the political system, the president is supremely positioned to exert influence over the public agenda. Unlike Congress, he is a lone public figure that has 24-hour news coverage of his activities and traditionally has had public airtime available to convey important messages. While the public may not tune into this coverage as much as they used to (Baum and Kernell 1999; Young and Perkins 2005), the public microscope does intensify each year around the time of the State of the Union Address. The news media begins to speculate on the contents of the message and TV stations typically block off air time to cover it. It is because of the routine nature and tradition of this speech that the public is likely to tune into it and absorb the president's message. Hence, the second hypothesis addresses this prospect.

$\mathrm{H}_{2}$ (Public Agenda Hypothesis): As the president's attention to a given policy area in the SUA increases, the public's attention to this same area is also likely to increase. 
Although previous research has considered alternative influences on the public agenda, such as the level of congressional attention to different issues (Edwards and Wood 1999; Wood and Peake 1998), international events (Hill 1998; Peake 2001), and the declining number of broadcast television households (Young and Perkins 2005), it has failed to account for the political environment. Since the purpose of the president's public speeches is often to circumvent an uncooperative Congress, especially one predisposed to blocking his policy priorities (Kernell 1997), the composition of Congress would seem to play a role in how effectively the president is able to reach his national constituency. Having a number of the president's co-partisans in office should make the president's job of agenda leadership easier. This is because the president does not have to compete with an alternative agenda, and Congressional leaders from the same party are likely to echo the president's priorities.

On the other hand, scholars have identified a number of problems that accompany divided government and the subsequent breakdown of the responsible party model of government (Sundquist 1988), such as the loss of electoral accountability (Fiorina 1996) and the increase in presidential vetoes (Rohde and Simon 1985). However, little, if any, attention has been devoted to how divided government may affect one of the key assumptions behind the responsible party model - that is that the majority party clearly communicates a set of policy priorities to the electorate. Just as divided government obscures policy responsibility and exacerbates partisan squabbles, it can also obscure the initial message to the public from the primary policy communicator, the president. As Fiorina notes, "Presidents blame Congress for obstructing carefully crafted solutions, while members of Congress attack the president for lack of leadership" $(1996,108)$. In this environment, competing messages may make it more difficult for the public to discern the president's priorities.

This is perhaps best exemplified just after the SUA when the Speaker of the House and Senate Majority Leader have an opportunity to convey their own agenda with a residual presidential audience. Thus, it is during these conditions that the president's message may become diluted and less likely to resonate with the public. Additionally, in news stories subsequent to the SUA, the media is more likely to cover continuing rebuttals to the president's agenda, which may also divert the public's attention. Given these distractions under divided government, the president should have a more difficult time directing public attention to his priorities. This is captured in the third hypothesis:

$\mathrm{H}_{3}$ (Divided Attention Hypothesis): Under periods of divided government, the president will be less likely to direct public attention to his priorities. 


\section{Data and Methodology}

This study encompasses the time period from 1954-2000, which spans the administrations of Eisenhower through Clinton. Three substantive policy areas, (1) crime, (2) education, and (3) health and social welfare, are examined to evaluate the relationship between the president's and the public's agenda. While Edwards and Woods (1999) investigated similar issues, this study differs from theirs in several ways. First, as mentioned above, I employ a single speech as the measure of the president's agenda because it is the most likely to be observed by the public on a consistent and annual basis. Edwards and Woods (1999) used all written and spoken communications in their indiscriminate measure of the president's agenda. Second, similar to Cohen (1995) and others (Hill 1998; Yates and Whitford 2005; Young and Perkins 2005), I directly measure the public's attention to different issues whereas Edwards and Woods (1999) use an indirect measure of the public, the media's attention. Additionally, I also analyze the impact of divided government on the president's ability to set the public's agenda, a factor previously unexplored in models of presidential agenda-setting. ${ }^{7}$

To test the reciprocal nature of the relationship between the president and the public, separate models estimate the impact of public opinion on the president's agenda and the impact of the president's agenda on public opinion. Using an interaction term, another model tests the impact of divided government on the president's influence over the public agenda to determine whether it is responsible for some of the president's declining influence. One last model examines the long-term impact of the president's agenda on public opinion by looking at public opinion polls late in the calendar year.

Public Opinion. ${ }^{8}$ The public opinion variable measures the public's attention to the three domestic policy areas at three different time points: (1) just prior to the SUA; (2) just after the SUA $;{ }^{9}$ and (3) at the end of the year. I used the poll question that typically asks respondents, "What issue do you consider to be the most important problem facing the nation at this time?"10 In the models testing the Presidential Agenda Hypothesis $\left(\mathrm{H}_{1}\right)$, Public Opinion serves as the dependent variable, while it functions as an independent variable in models testing the second and third hypothesis.

Presidential Mentions. Another important variable in the models is the Presidential Mentions variable, which captures the president's rhetorical agenda. Similar to Cohen (1997), I conducted a content analysis of State of the Union Addresses in order to discern the president's rhetorical attention to different policy areas. ${ }^{11}$ To arrive at this variable, I counted every sentence in the addresses and categorized them into one of the three policy categories. This procedure produced the total number of sentences devoted to each policy area. Presidential Mentions is an independent variable in the models 
testing the first hypothesis, while it is the dependent variable in the rest of the models.

Divided Government. The Divided Government variable in the models captures the effects of divided government on the president's ability to set the public agenda. This variable is coded as a simple dichotomous variable where 0 represents unified government and a 1 represents divided. When this variable is interacted with the Presidential Mentions variable, I expect the president to be less likely to direct public attention to his priorities.

Monthly Approval. As a control variable, I include a measure for the president's approval in the month of his speech. In the model testing the Presidential Agenda Hypothesis $\left(\mathrm{H}_{1}\right)$, I expect increases in approval to boost the president's attention to crime, education, and health and social welfare because a more popular president is likely to be presiding over a sound economy and can more freely direct his attention to non-economic issues. In the rest of the models that examine the impact of the president's agenda on public opinion, it should also increase public attention to different issues because individuals are more likely to follow a popular leader.

Congressional Attention. Much of the scholarship on agenda-setting focuses on whether the president or Congress is more adept at setting each other's and the media's agenda (Edwards and Wood 1999; Eshbaugh-Soha and Peake 2004, 2005; Grusczynski 2004). Here, I include a variable to capture Congress's attention to the relevant issues, but code it in a different way from previous scholars. Most scholars have counted the number of committee hearing days devoted to a policy area to arrive at a proxy of congressional attention (Edwards and Wood 1999; Eshbaugh-Soha and Peake 2004, 2005). However, this measure may not be appropriate for our purposes here since the general public is unlikely to follow congressional committee activity. Instead, I employ the number of roll call votes considered in the previous year for a given policy area minus votes that the president supported as a measure of congressional attention. This measure is advantageous because roll call votes capture legislation that has made it through the hearing process and is in the final stages of legislative consideration. Given the more serious nature of roll call votes on the floor, the public is more likely to be exposed to these votes through newspaper or television accounts. Thus, roll call votes that the president takes no position on or does not support seem to be a more valid measure of how Congress may divert attention away from the president. Again, this does not mean that the number of hearing days is not more suitable for the studies that strictly use media attention as a substitute for the public. These data are taken from the Congressional Quarterly Almanac.

Economic Measures. In each of the models, I include control variables that measure the unemployment rate and the inflation rate in the month prior 
to the speech. These variables function as objective indicators of the status of the economy where higher levels are expected to distract both the president's and the public's attention from each of the respective issues.

Statistical Method. Since the data in this study are an annual time series, I employ time series analysis to estimate the relationship between the president's and the public's agenda. Specifically, I use an Autoregressive procedure to control for autocorrelation in the models and also estimate robust standard errors to avoid the presence of heteroskedasticity. I also test for any residual autocorrelation in the models using a Durbin Watson $h$ test. $^{12}$

\section{Data Analysis and Results}

Table 1 provides the results for testing the Presidential Agenda Hypothesis $\left(\mathrm{H}_{1}\right)$ in all three issue areas. The dependent variable in the models is Presidential Mentions, which is the number of sentences devoted to each policy area in State of the Union Addresses. This allows us to determine whether the president incorporates public opinion into his policy agenda. As shown in Table 1, there is some support for the hypothesis as two of the three policy areas demonstrate that public opinion positively and significantly impacts the president's agenda. ${ }^{13}$ In the crime model in Column 1 , Public Opinion is marginally significant at the 10 percent level. A one standard deviation change in Public Opinion (7.5 percent) results in another 2 sentences devoted to crime in the president's message. This finding is similar to Edwards and Wood's (1999) study because they found that media attention to crime also influenced the president's agenda.

In the education model, Public Opinion is significantly different than zero at the higher confidence threshold of 5 percent. In terms of the substantive effects, a 2 percent increase (about a one standard deviation change) in the percentage of the public identifying education as the most important problem adds another 10 sentences to the president's speech. Compared with crime, it appears the president is much more responsive to the public's concern with education, which is probably due to its increasing salience in the 1990s relative to earlier decades. In Column 3, the Public Opinion variable for health and social welfare is not significant at conventional levels. It seems that presidents do not respond to public awareness of health and social welfare as they do for crime and education, which, is again similar to the findings in Edwards and Wood (1999).

Overall the models explain a reasonably good amount of the variance in the president's agenda ranging from 30 percent in the crime model to nearly 50 percent in the education model. With regard to other variables of interest to the literature, Congressional Attention is significant only in the crime 


\section{Table 1. The Impact of Public Opinion on the President's Agenda, 1954-2000}

\begin{tabular}{|c|c|c|c|}
\hline Independent Variables & $\begin{array}{l}\text { Crime } \\
(1)\end{array}$ & $\begin{array}{l}\text { Education } \\
\text { (2) }\end{array}$ & $\begin{array}{c}\text { Health/ } \\
\text { Social Welfare } \\
\text { (3) }\end{array}$ \\
\hline Presidential Mentions $_{(\mathrm{t}-1)}$ & - & - & $\begin{array}{l}.62^{* * * *} \\
(.16)\end{array}$ \\
\hline Pre-Speech Public Opinion & $\begin{array}{l}.29 * \\
(.17)\end{array}$ & $\begin{array}{l}5.32 * * \\
(1.84)\end{array}$ & $\begin{array}{l}.41 \\
(.53)\end{array}$ \\
\hline Divided Government & $\begin{array}{l}-1.31 \\
(2.27)\end{array}$ & $\begin{array}{l}2.37 \\
(2.76)\end{array}$ & $\begin{array}{c}-5.99 \\
(10.09)\end{array}$ \\
\hline Monthly Approval & $\begin{array}{l}-.17 \\
(.11)\end{array}$ & $\begin{array}{l}.12 \\
(.12)\end{array}$ & $\begin{array}{l}-.28 \\
(.26)\end{array}$ \\
\hline $\begin{array}{l}\text { Congressional Attention } \\
\text { (Previous Year) }\end{array}$ & $\begin{array}{l}.19^{* * *} \\
(.06)\end{array}$ & $\begin{array}{l}-.14 \\
(.13)\end{array}$ & $\begin{array}{l}.21 \\
(.17)\end{array}$ \\
\hline $\begin{array}{l}\text { Inflation } \\
\text { (Prior Month) }\end{array}$ & $\begin{array}{l}-.60 * * \\
(.27)\end{array}$ & $\begin{array}{l}.37 \\
(.36)\end{array}$ & $\begin{array}{l}-1.98^{*} \\
(1.12)\end{array}$ \\
\hline $\begin{array}{l}\text { Unemployment } \\
\text { (Prior Month) }\end{array}$ & $\begin{aligned}-1.56 \\
(.95)\end{aligned}$ & $\begin{array}{l}-1.02 \\
(1.04)\end{array}$ & $\begin{array}{l}-.95 \\
(1.57)\end{array}$ \\
\hline Constant & $\begin{array}{l}23.16^{*} \\
(12.04)\end{array}$ & $\begin{array}{l}-.11 \\
(9.50)\end{array}$ & $\begin{array}{r}30.72 * \\
(17.44)\end{array}$ \\
\hline $\mathrm{N}$ & 47 & 47 & 47 \\
\hline $\begin{array}{l}\text { Adjusted } \mathrm{R}^{2} \\
\text { F } \\
\text { Durbin-Watson's } h \\
\text { Model Type }\end{array}$ & $\begin{array}{l}.30 \\
7.09 * * * \\
.01 \\
\text { OLS }\end{array}$ & $\begin{array}{l}\quad .49 \\
2.68 * * \\
3.146 \\
\text { OLS }\end{array}$ & $\begin{array}{l}.35 \\
4.34 * * * \\
1.50 \\
\text { AR1 }\end{array}$ \\
\hline \multicolumn{4}{|c|}{$\begin{array}{l}{ }^{*} \mathrm{p}<.10 \text { (two-tailed) }{ }^{* *} \mathrm{p}<.05 \text { (two-tailed) }{ }^{* * *} \mathrm{p}<.01 \text { (two-tailed) } \\
\text { Note: The dependent variable in each model is the number of sentences in State of the Union } \\
\text { messages devoted to each policy area. Robust standard errors are in parentheses. }\end{array}$} \\
\hline
\end{tabular}

model suggesting that the president responds to congressional roll call activity on crime-related bills from the previous year, but not to bills in the other two areas. The variable is highly significant at the 1 percent level and results in an increase of .19 sentences, which translates into a one standard deviation change (about 20 roll call votes) of about 4 sentences. This contradicts Edwards and Wood's (1999) findings since they show that congressional activity did not influence the president's agenda in any of the three policy areas. 
We now turn our attention to the impact of the presidential agenda and divided government on the public agenda. In these models, shown in Tables 2-4, the dependent variable is Public Opinion, which is the percentage of the public identifying an issue area as the most important problem facing the nation. Three models are estimated for each policy area. The first (Column 1) and third models (Column 3) in each table test the Public Agenda Hypothesis $\left(\mathrm{H}_{2}\right)$, which suggests that increases in the president's attention to crime, education, and health and social welfare should increase the public salience of these issues. The Column 1 models assess the short-term impact of the president's statements on public opinion by employing polls from immediately after his speech, while the Column 3 models estimate the long-term impact using polls late in the calendar year. The models in Column 2 in each of the tables tests the Divided Attention Hypothesis $\left(\mathrm{H}_{3}\right)$, which posits that divided government should reduce the president's influence over the public agenda.

We begin with the results of the crime models presented in Table 2 . There is some support for the Public Agenda Hypothesis in the long-term model, but not in the short-term model. In Column 1, the short-term model, the coefficient for Presidential Mentions is not significant at convention levels, which means that the president does not immediately draw public attention to crime after delivery of State of the Union Addresses. However, instead, the president is able to draw public attention to crime later in the year as demonstrated by the results in Column 3. Presidential Mentions is significant at the 5 percent level and boosts public awareness of crime by about .39 percent. With regard to the substantive impact, a one standard deviation change (about 9 sentences) in the number of crime sentences increases public salience by nearly 4 percent. The discrepancy in the short and long-term effects can probably be explained by the congressional and media response to the president's speech. Congress may initiate legislation in the wake of the speech, while news stories may follow up on the president's proposals, all of which may occur several months after the speech. Therefore, the president's impact may be delayed in some cases, but eventually resonates with the public due to the flurry of elite discourse on the issue. This finding contradicts previous research by Cohen (1995) and Edwards and Wood (1999). In Cohen's (1995) study, he assessed the longterm impact of presidential rhetoric in a similar fashion, but found long-term effects only in the foreign policy arena. On the other hand, Edwards and Wood (1999) demonstrate the president has no influence over the media's attention to crime.

Moving to the impact of divided government, I also find support for the Divided Attention Hypothesis in Column 2, but it is not immediately obvious due to the estimation of the interactive model. To evaluate the 


\section{Table 2. Impact of Presidential Mentions and Divided Government on Public Opinion: Crime, 1954-2000}

\begin{tabular}{|c|c|c|c|}
\hline Independent Variables & $\begin{array}{l}\text { Short-term } \\
\text { Impact } \\
(1)\end{array}$ & $\begin{array}{c}\text { Divided } \\
\text { Government } \\
\text { Impact } \\
\text { (2) }\end{array}$ & $\begin{array}{l}\text { Long-term } \\
\text { Impact } \\
\text { (3) }\end{array}$ \\
\hline Presidential Mentions & $\begin{array}{l}.29 \\
(.20)\end{array}$ & $\begin{array}{l}.78 * * \\
(.35)\end{array}$ & $\begin{array}{l}.39 * * \\
(.19)\end{array}$ \\
\hline Pre-Speech Public Opinion & $\begin{array}{l}.83^{*} \\
(.41)\end{array}$ & $\begin{array}{l}.79 * * \\
(.32)\end{array}$ & $\begin{array}{l}1.03 * * * \\
(.33)\end{array}$ \\
\hline Divided Government & $\begin{array}{l}1.05 \\
(3.94)\end{array}$ & $\begin{array}{c}4.99 \\
(3.28)\end{array}$ & $\begin{array}{c}.80 \\
(3.04)\end{array}$ \\
\hline $\begin{array}{l}\text { Divided Government } x \\
\text { Presidential Mentions }\end{array}$ & - & $\begin{array}{l}-.73 * \\
(.39)\end{array}$ & - \\
\hline Monthly Approval & $\begin{array}{l}.05 \\
(.12)\end{array}$ & $\begin{array}{l}.14 \\
(.14)\end{array}$ & $\begin{array}{l}.04 \\
(.09)\end{array}$ \\
\hline $\begin{array}{l}\text { Congressional Attention } \\
\text { (Previous Year) }\end{array}$ & $\begin{array}{l}-.18^{*} \\
(.10)\end{array}$ & $\begin{array}{l}-.15 \\
(.09)\end{array}$ & $\begin{array}{l}-.12 \\
(.11)\end{array}$ \\
\hline $\begin{array}{l}\text { Inflation } \\
\text { (Prior Month) }\end{array}$ & $\begin{array}{l}.61 \\
(.41)\end{array}$ & $\begin{array}{l}.71 * \\
(.41)\end{array}$ & $\begin{array}{l}.62 \\
(.39)\end{array}$ \\
\hline $\begin{array}{l}\text { Unemployment } \\
\text { (Prior Month) }\end{array}$ & $\begin{array}{l}-.03 \\
(.86)\end{array}$ & $\begin{array}{l}.40 \\
(.92)\end{array}$ & $\begin{array}{c}.41 \\
(.82)\end{array}$ \\
\hline Constant & $\begin{array}{c}-3.12 \\
(11.19)\end{array}$ & $\begin{array}{l}-14.37 \\
(14.14)\end{array}$ & $\begin{array}{l}-4.41 \\
(9.25)\end{array}$ \\
\hline $\mathrm{N}$ & 47 & 47 & 47 \\
\hline $\begin{array}{l}\text { Adjusted } \mathrm{R}^{2} \\
\mathrm{~F} \\
\text { Durbin-Watson's } h \\
\text { Model Type }\end{array}$ & $\begin{array}{l}.55 \\
5.80 * * * \\
.00 \\
\text { AR2 }\end{array}$ & $\begin{array}{l}.59 \\
5.64 * * * \\
.03 \\
\text { AR2 }\end{array}$ & $\begin{array}{l}.56 \\
5.33 * * * \\
.05 \\
\text { AR3 }\end{array}$ \\
\hline \multicolumn{4}{|c|}{$\begin{array}{l}* \mathrm{p}<.10 \text { (two-tailed) } * * \mathrm{p}<.05 \text { (two-tailed) } * * * \mathrm{p}<.01 \text { (two-tailed) } \\
\text { Note: The dependent variable in each model is the percentage of the public identifying crime as the } \\
\text { most important issue facing the nation. The models in Columns } 1 \text { and } 2 \text { use available opinion polls } \\
\text { immediately after the president's State of the Union address, while the model in Column } 3 \text { uses the } \\
\text { latest opinion poll available at the end of the year. Robust standard errors are in parentheses. }\end{array}$} \\
\hline
\end{tabular}


effects of an interactive term, it is necessary to determine whether the model including the multiplicative variable significantly improves upon the model without the interactive term. In this case, an F-test of the interaction model indicates that the addition of the interactive term significantly improves upon the baseline model $(\mathrm{p}<.10)$. Also, since this is an interactive model, the coefficients are not interpreted the same as additive models, which was the case in Columns 1 and 3 (Friedrich 1982). Instead, the impact of Presidential Mentions is conditional on the presence of divided government. With this in mind, an increase in Presidential Mentions under periods of divided government increases the public salience of crime by .5 percent (i.e., (.78) + (1) $(-.73)=.5)$. Substantively, when divided government is present, this means that a one standard deviation change in presidential mentions of crime (9.4) results in an additional 4.5 percent (i.e., $9.4 * .5=4.5$ ) of the public that consider crime the most important problem.

Support for the Divided Attention Hypothesis becomes clearer when we consider the president's impact under unified government. To arrive at the substantive impact, the net effect of Presidential Mentions conditioned by unified government becomes .78 (i.e., $(.78)+(0)(-.73)=.78)$ instead of .5 in the divided setting. Again, using a one standard deviation change in Presidential Mentions, this translates into an increase in public attention to crime of 7.3 percent (i.e., $.73 * 9.4=7.3$ ) under unified government. Comparing the substantive effects of divided versus unified government, the former results in a decrease in the president's influence over the public agenda of nearly 3 percent. This appears to be the first evidence that the president's impact is diluted under divided government, which may partially explain some of the contradictory findings regarding the president's influence over the public agenda.

Table 3 provides the results for the three models in education. As a whole, these models provide strong support for the Public Agenda Hypothesis, but none for the Divided Attention Hypothesis. In Column 1, Presidential Mentions is highly significant at the 1 percent level and results in a positive impact on the public salience of education in the short term. An increase of about 15 sentences (one standard deviation) by presidents in the SUA increases public attention to education by about 2 percent, a small, but not inconsequential amount. As shown in Column 3, this influence dissipates slightly by the end of the year, but the effect remains highly significant $(p<.01)$. Using the common value of a one standard deviation change, Presidential Mentions increases public salience towards the end of the year by slightly more than 1 percent.

While there is support for the Public Agenda Hypothesis in the short and long term, this support does not extend to the interactive model and the Divided Attention Hypothesis. The interactive term in Column 2 is not 


\section{Table 3. Impact of Presidential Mentions and Divided Government on Public Opinion: Education, 1954-2000}

\begin{tabular}{|c|c|c|c|}
\hline Independent Variables & $\begin{array}{l}\text { Short-term } \\
\text { Impact } \\
(1)\end{array}$ & $\begin{array}{l}\text { Divided } \\
\text { Government } \\
\text { Impact } \\
\text { (2) }\end{array}$ & $\begin{array}{l}\text { Long-term } \\
\text { Impact } \\
(3)\end{array}$ \\
\hline Presidential Mentions & $\begin{array}{l}.14 * * * \\
(.04)\end{array}$ & $\begin{array}{l}.13 \\
(.11)\end{array}$ & $\begin{array}{l}.10 * * * \\
(.04)\end{array}$ \\
\hline Pre-Speech Public Opinion & $\begin{array}{l}.21 \\
(.57)\end{array}$ & $\begin{array}{l}.20 \\
(.58)\end{array}$ & $\begin{array}{l}.27 \\
(.48)\end{array}$ \\
\hline Divided Government & $\begin{array}{l}-.33 \\
(.58)\end{array}$ & $\begin{array}{l}-.41 \\
(.52)\end{array}$ & $\begin{array}{l}-.18 \\
(.43)\end{array}$ \\
\hline $\begin{array}{l}\text { Divided Government x } \\
\text { Presidential Mentions }\end{array}$ & - & $\begin{array}{l}.01 \\
(.11)\end{array}$ & - \\
\hline Monthly Approval & $\begin{array}{l}-.01 \\
(.02)\end{array}$ & $\begin{array}{l}-.01 \\
(.02)\end{array}$ & $\begin{array}{l}-.01 \\
(.02)\end{array}$ \\
\hline $\begin{array}{l}\text { Congressional Attention } \\
\text { (Previous Year) }\end{array}$ & $\begin{array}{l}.03 \\
(.02)\end{array}$ & $\begin{array}{l}.03 \\
(.02)\end{array}$ & $\begin{array}{l}-.00 \\
(.02)\end{array}$ \\
\hline $\begin{array}{l}\text { Inflation } \\
\text { (Prior Month) }\end{array}$ & $\begin{array}{l}-.04 \\
(.08)\end{array}$ & $\begin{array}{l}-.04 \\
(.07)\end{array}$ & $\begin{array}{l}-.01 \\
(.07)\end{array}$ \\
\hline $\begin{array}{l}\text { Unemployment } \\
\text { (Prior Month) }\end{array}$ & $\begin{array}{l}.01 \\
(.19)\end{array}$ & $\begin{array}{l}.01 \\
(.18)\end{array}$ & $\begin{array}{c}.08 \\
(.18)\end{array}$ \\
\hline Constant & $\begin{array}{c}.70 \\
(1.47)\end{array}$ & $\begin{array}{c}.75 \\
(1.51)\end{array}$ & $\begin{array}{c}.31 \\
(1.63)\end{array}$ \\
\hline $\mathrm{N}$ & 47 & 47 & 46 \\
\hline $\begin{array}{l}\text { Adjusted } \mathrm{R}^{2} \\
\mathrm{~F} \\
\text { Durbin-Watson's } h \\
\text { Model Type }\end{array}$ & $\begin{array}{l}.58 \\
18.10^{* * *} \\
1.63 \\
\text { AR1 }\end{array}$ & $\begin{array}{l}.57 \\
18.11^{* * *} \\
1.70 \\
\text { AR1 }\end{array}$ & $\begin{array}{c}.65 \\
12.59 * * * \\
1.04 \\
\text { AR2 }\end{array}$ \\
\hline \multicolumn{4}{|c|}{$\begin{array}{l}* \mathrm{p}<.10 \text { (two-tailed) } * * \mathrm{p}<.05 \text { (two-tailed) } * * * \mathrm{p}<.01 \text { (two-tailed) } \\
\text { Note: The dependent variable in each model is the percentage of the public identifying education as } \\
\text { the most important issue facing the nation. The models in Columns } 1 \text { and } 2 \text { use available opinion } \\
\text { polls immediately after the president's State of the Union address, while the model in Column } 3 \text { uses } \\
\text { the latest opinion poll available at the end of the year. Robust standard errors are in parentheses. }\end{array}$} \\
\hline
\end{tabular}


Table 4. Impact of Presidential Mentions and Divided Government on Public Opinion: Health and Social Welfare, 1954-2000

\begin{tabular}{|c|c|c|c|}
\hline Independent Variables & $\begin{array}{l}\text { Short-term } \\
\text { Impact } \\
\text { (1) }\end{array}$ & $\begin{array}{l}\text { Divided } \\
\text { Government } \\
\text { Impact } \\
(2)\end{array}$ & $\begin{array}{l}\text { Long-term } \\
\text { Impact } \\
\text { (3) }\end{array}$ \\
\hline Presidential Mentions & $\begin{array}{l}.22 * * * \\
(.05)\end{array}$ & $\begin{array}{l}.29 * * * \\
(.03)\end{array}$ & $\begin{array}{l}.17 * * * \\
(.04)\end{array}$ \\
\hline Pre-Speech Public Opinion & $\begin{array}{c}.47^{*} \\
(.25)\end{array}$ & $\begin{array}{c}.48 * \\
(.27)\end{array}$ & $\begin{array}{c}.26 \\
(.23)\end{array}$ \\
\hline Divided Government & $\begin{array}{l}1.14 \\
(2.67)\end{array}$ & $\begin{array}{l}4.07 \\
(2.45)\end{array}$ & $\begin{array}{c}.55 \\
(3.63)\end{array}$ \\
\hline $\begin{array}{l}\text { Divided Government x } \\
\text { Presidential Mentions }\end{array}$ & - & $\begin{array}{l}-.12 * \\
(.06)\end{array}$ & - \\
\hline Monthly Approval & $\begin{array}{l}.04 \\
(.08)\end{array}$ & $\begin{array}{l}.03 \\
(.07)\end{array}$ & $\begin{array}{l}.13 \\
(.12)\end{array}$ \\
\hline $\begin{array}{l}\text { Congressional Attention } \\
\text { (Previous Year) }\end{array}$ & $\begin{array}{c}.07 \\
(.04)\end{array}$ & $\begin{array}{l}.06 \\
(.04)\end{array}$ & $\begin{array}{l}.12 * * \\
(.06)\end{array}$ \\
\hline $\begin{array}{l}\text { Inflation } \\
\text { (Prior Month) }\end{array}$ & $\begin{array}{l}-.34 \\
(.35)\end{array}$ & $\begin{array}{l}-.24 \\
(.37)\end{array}$ & $\begin{array}{l}-.61^{*} \\
(.36)\end{array}$ \\
\hline $\begin{array}{l}\text { Unemployment } \\
\text { (Prior Month) }\end{array}$ & $\begin{array}{c}.01 \\
(.77)\end{array}$ & $\begin{array}{l}-.13 \\
(.75)\end{array}$ & $\begin{array}{l}.60 \\
(.80)\end{array}$ \\
\hline Constant & $\begin{array}{l}-5.30 \\
(6.72)\end{array}$ & $\begin{array}{l}-5.34 \\
(6.57)\end{array}$ & $\begin{array}{r}-12.84 \\
(9.29)\end{array}$ \\
\hline $\mathrm{N}$ & 47 & 47 & 47 \\
\hline $\begin{array}{l}\text { Adjusted } \mathrm{R}^{2} \\
\text { F } \\
\text { Durbin-Watson's } h \\
\text { Model Type }\end{array}$ & $\begin{array}{l}.56 \\
8.53^{* * *} \\
1.83 \\
\text { AR1 }\end{array}$ & $\begin{array}{l}.57 \\
5.64 * * * \\
2.03 \\
\text { AR1 }\end{array}$ & $\begin{array}{l}.38 \\
12.46^{* * *} \\
1.70 \\
\text { AR1 }\end{array}$ \\
\hline \multicolumn{4}{|c|}{$\begin{array}{l}* \mathrm{p}<.10 \text { (two-tailed) } * * \mathrm{p}<.05 \text { (two-tailed) } * * * \mathrm{p}<.01 \text { (two-tailed) } \\
\text { Note: The dependent variable in each model is the percentage of the public identifying health and } \\
\text { social welfare as the most important issue facing the nation. The models in Columns } 1 \text { and } 2 \text { use } \\
\text { available opinion polls immediately after the president's State of the Union address, while the model } \\
\text { in Column } 3 \text { uses the latest opinion poll available at the end of the year. Robust standard errors are in } \\
\text { parentheses. }\end{array}$} \\
\hline
\end{tabular}


significant nor is it pointed in the anticipated negative direction. Ostensibly, divided government does not seem to decrease the president's impact on the public agenda for education. This may be an indicator that education has become a more bipartisan issue and that the opposition party is less likely to offer a competing agenda that may divert the public's attention. The results for health and social welfare, which is normally considered a more partisan issue, seem to provide further evidence of this speculation.

The results for health and social welfare are shown in Table 4. They indicate support for both hypotheses tested. As the coefficients for Presidential Mentions demonstrate, the president affects public opinion on health and social welfare both in the short and long term (Columns 1 and 3). Similar to education, both variables are highly significant and boost the percentage of the public identifying the issue as important. In the short term, an increase of about 27 sentences (one standard deviation) results in an additional 6 percent of the public identifying health and social welfare as important. In the long term, the impact diminishes slightly, but still increases public salience by about 5 percent. These findings suggest the president's influence remains strong throughout the year, which contradicts Cohen's (1995) research because he found no long-term impacts in domestic policy.

With regard to the impact of divided government, it appears to reduce the president's influence compared to the unified setting. Once again, due to the interaction term in the model, the results cannot be directly interpreted. With the addition of the multiplicative term, an F-test indicates that the interaction model significantly improves the explanatory power from the baseline model $(p<.10)$. The overall impact of divided government can be illustrated comparing one standard deviation changes in Presidential Mentions under divided versus unified government. Under unified government, 27 sentences devoted to health and social welfare increases its public salience by about 8 percent (i.e., $(.29)+(0)(-.12)=.29)$. With the opposition party controlling Congress, the same number of sentences increases public salience by only 5 percent (i.e., $(.29)+(1)(-.12)=.17)$, which is a difference of about 3 percent. Along with the results in the crime model, this further suggests that divided government may limit the president's ability to set the public agenda.

\section{Discussion and Conclusion}

The purpose of this paper was threefold. First, I sought to update and extend work done by Cohen (1995) and others (Hill 1998; Young and Perkins 2005) that examines the relationship between presidential and public attention to domestic policy. In this regard, I investigated three domestic policy issues previously not examined and an additional 11 years of data. 
This update is important because recent scholarship has begun to question the president's impact on public opinion (Edwards 2003; Edwards and Wood 1999; Eshbaugh-Soha and Peake 2004). However, my research suggests that the measurement of the agendas of the president and the public may contribute to the mixed picture on the president-public link. In two of the three domestic policy areas, education and health and social welfare, it seems the president is able to direct public attention to issues with a single major speech both over the short and long term, while this is the case only in the long term for crime issues. This is in contradistinction to other research, which uses alternative measures and finds a more limited agenda-setting role for the president.

Additionally, although Cohen (1995) found that the president could direct public attention to the economy, civil rights, and foreign policy, he found no significant relationship in overall domestic policy. The evidence presented here fills in the missing piece of whether the president's influence extends into other domestic areas. These findings tend to support the idea of a "presidency-centered" model of policymaking (Covington, Wrighton, and Kinney 1995), especially in light of the recent findings by Canes-Wrone and de Marchi (2002), who found that the president can translate public issue salience and high approval ratings into legislative success. Because this research demonstrates that the president is able to direct public attention to his agenda priorities, it suggests the president is perhaps also able to take the reins of his domestic agenda and convert these priorities into legislative victories.

The second purpose of this paper concerned the direction of influence between the president and the public. Of the studies that directly measure public rather than media attention (Cohen 1997; Hill 1998) to issues, the evidence thus far has found no reciprocal influence between the president and the public on domestic non-economic issues. The findings in this study suggest the influence flows both ways on crime and education, but not on health and social welfare. In the latter case, the influence extends only one way, from the president to the public. These results suggest that future studies should not assume the arrow of causality points only in one direction.

The last purpose of this paper was to explore the impact of divided government on the president's influence over the public. Whereas some research has examined divided government's role in what makes it on to the president's agenda, to my knowledge, no research has looked at this factor's impact on the president's communications with the public. Based on these results, divided government seems to limit the president's ability to set the public's agenda. While divided government did not seem to be a significant factor in setting the public's education agenda, compared with the unified setting, it did reduce the president's influence over the public on crime and health and social welfare issues. 
Along with various measurements of the key variables in agendasetting models, divided government also may partially explain some of the mixed results regarding the president's effect on the public. Some, not all, of the previous research on agenda-setting that assigns a less influential role for the president examined time periods dominated by divided government (Edwards and Wood 1999; Eshbaugh-Soha and Peake 2005; Wood and Peake 1998). For example, the Edwards and Wood (1999) article investigated the time period between 1984 and 1994, a span that included eight out of 10 years of divided control (Clinton had unified government from 199394). Additionally, Eshbaugh-Soha and Peake (2005) examined the period from 1981-2000, which had 18 out of 20 years of divided government. While it is premature to conclude that this is the reason for the ebb and flow of the president's agenda-setting powers, it should be regarded as one of the suspects, along with the declining television audience (Baum and Kernell 1999; Young and Perkins 2005).

\section{APPENDICES}

Appendix A. Descriptive Statistics for Variables

\begin{tabular}{|c|c|c|c|c|}
\hline Variable & Mean & $\begin{array}{l}\text { Standard } \\
\text { Deviation }\end{array}$ & $\begin{array}{l}\text { Minimum } \\
\text { Value }\end{array}$ & $\begin{array}{c}\text { Maximum } \\
\text { Value }\end{array}$ \\
\hline
\end{tabular}

Pre-Speech Public Opinion

\begin{tabular}{|c|c|c|c|}
\hline Crime & 7.17 & 7.50 & 0 \\
\hline Education & 1.53 & 1.97 & 0 \\
\hline ial Welfare & 6.60 & 8.90 & 0 \\
\hline
\end{tabular}

Health and Social Welfare

1.53
6.60

8.90

48

Short-Term Post-Speech Public Opinion

Crime

Education $\quad 1.85$

13.58

3.04

8.83

11.55

61

11

Health and Social Welfare

\section{pinion}

Crime $\quad 10.04$

Education

2.19

11.40

3.12

Health and Social Welfare

8.23

10.44

$\begin{array}{ll}0 & 61 \\ 0 & 11 \\ 0 & 48\end{array}$

Presidential Mentions

$\begin{array}{rrrrr}\text { Crime } & 6.38 & 9.37 & 0 & 34 \\ \text { Education } & 10.10 & 14.54 & 0 & 75 \\ \text { Health and Social Welfare } & 24.36 & 27.31 & 0 & 129\end{array}$

Congressional Attention

$\begin{array}{rcccr}\text { Crime } & 16.98 & 20.33 & 0 & 110 \\ \text { Education } & 15.53 & 16.87 & 0 & 62 \\ \text { Health and Social Welfare } & 49.83 & 32.49 & 2 & 132 \\ & & & & \text { appendix continues ... }\end{array}$


Appendices (continued)

\begin{tabular}{|c|c|c|c|c|}
\hline \multicolumn{5}{|l|}{ Appendix A (continued) } \\
\hline Variable & Mean & $\begin{array}{l}\text { Standard } \\
\text { Deviation }\end{array}$ & $\begin{array}{l}\text { Minimum } \\
\text { Value }\end{array}$ & $\begin{array}{l}\text { Maximum } \\
\text { Value }\end{array}$ \\
\hline \multicolumn{5}{|c|}{ Presidential Mentions $x$ Divided Government } \\
\hline Crime & 4.51 & 8.36 & 0 & 34 \\
\hline $\begin{array}{l}\text { Education } \\
\text {. }\end{array}$ & 7.96 & 14.97 & 0 & 75 \\
\hline Health and Social Welfare & 15.85 & 24.20 & 0 & 94 \\
\hline Inflation (Prior Month) & 3.81 & 3.46 & -1.62 & 14.13 \\
\hline Unemployment (Prior Month) & 5.81 & 1.47 & 3.4 & 10.30 \\
\hline Divided Government & .64 & .49 & 0 & 1 \\
\hline Monthly Approval & 59.49 & 12.66 & 27 & 83 \\
\hline
\end{tabular}

Appendix B. Presidential Mentions by Issue and Year

\begin{tabular}{|c|c|c|c|c|}
\hline President & Year & Crime & Education & $\begin{array}{l}\text { Health and } \\
\text { Social Welfare }\end{array}$ \\
\hline \multirow[t]{7}{*}{ Eisenhower } & 1954 & 0 & 6 & 26 \\
\hline & 1955 & 3 & 9 & 33 \\
\hline & 1956 & 0 & 13 & 44 \\
\hline & 1957 & 0 & 3 & 0 \\
\hline & 1958 & 0 & 9 & 0 \\
\hline & 1959 & 0 & 10 & 0 \\
\hline & 1960 & 0 & 6 & 0 \\
\hline \multirow[t]{3}{*}{ Kennedy } & 1961 & 1 & 6 & 6 \\
\hline & 1962 & 0 & 22 & 18 \\
\hline & 1963 & 1 & 3 & 11 \\
\hline \multirow[t]{5}{*}{ Johnson } & 1964 & 0 & 2 & 29 \\
\hline & 1965 & 4 & 12 & 9 \\
\hline & 1966 & 3 & 0 & 8 \\
\hline & 1967 & 20 & 5 & 15 \\
\hline & 1968 & 29 & 1 & 12 \\
\hline \multirow[t]{6}{*}{ Nixon } & 1969 & 3 & 1 & 9 \\
\hline & 1970 & 13 & 0 & 5 \\
\hline & 1971 & 0 & 0 & 21 \\
\hline & 1972 & 1 & 12 & 4 \\
\hline & 1973 & 0 & 0 & 3 \\
\hline & 1974 & 4 & 8 & 20 \\
\hline \multirow[t]{2}{*}{ Ford } & 1975 & 0 & 0 & 0 \\
\hline & 1976 & 26 & 0 & 42 \\
\hline \multirow[t]{4}{*}{ Carter } & 1977 & 0 & 0 & 20 \\
\hline & 1978 & 0 & 0 & 2 \\
\hline & 1979 & 0 & 0 & 6 \\
\hline & 1980 & 0 & 0 & 3 \\
\hline
\end{tabular}




\section{Appendices (continued)}

\begin{tabular}{|c|c|c|c|c|}
\hline \multicolumn{5}{|c|}{ Appendix B (continued) } \\
\hline President & Year & Crime & Education & $\begin{array}{l}\text { Health and } \\
\text { Social Welfare }\end{array}$ \\
\hline \multirow[t]{8}{*}{ Reagan } & 1981 & 0 & 5 & 25 \\
\hline & 1982 & 1 & 0 & 28 \\
\hline & 1983 & 4 & 7 & 32 \\
\hline & 1984 & 2 & 12 & 3 \\
\hline & 1985 & 12 & 6 & 15 \\
\hline & 1986 & 0 & 1 & 8 \\
\hline & 1987 & 0 & 4 & 11 \\
\hline & 1988 & 0 & 9 & 18 \\
\hline \multirow[t]{4}{*}{ Bush } & 1989 & 15 & 21 & 31 \\
\hline & 1990 & 1 & 22 & 16 \\
\hline & 1991 & 6 & 1 & 3 \\
\hline & 1992 & 10 & 10 & 40 \\
\hline \multirow[t]{8}{*}{ Clinton } & 1993 & 5 & 13 & 29 \\
\hline & 1994 & 22 & 9 & 129 \\
\hline & 1995 & 16 & 8 & 68 \\
\hline & 1996 & 30 & 21 & 50 \\
\hline & 1997 & 6 & 75 & 49 \\
\hline & 1998 & 10 & 27 & 61 \\
\hline & 1999 & 18 & 50 & 94 \\
\hline & 2000 & 34 & 46 & 89 \\
\hline
\end{tabular}

\section{NOTES}

${ }^{1}$ Edwards and Wood (1999) examine crime, healthcare, and education in their study of presidential agenda-setting, but as will be discussed later, they do not directly measure public attention to these issues.

${ }^{2}$ A larger literature on elite-mass linkages exists, which focuses on elites other than the president, such as high-ranking department officials and state party elites (Cunningham and Moore 1997; Hill and Hinton-Andersson 1995). However, I focus my analysis on those studies specifically dealing with the president.

${ }^{3}$ Another possible way to capture the president's agenda may be to use all televised speeches and not written statements. However, this measure is also fraught with problems as well. First, televised speeches beyond the SUA are likely to be policy-specific speeches, which tend to focus on issues unrelated to the ones studied here (i.e., foreign policy). Second, research by Baum and Kernell (1999) indicates that, unlike other speeches, presidents strategically schedule their State of the Union Addresses to maximize their audiences. As such, the inclusion of less prominent speeches may weaken the president's impact on public opinion. Lastly, one purpose of this study is to examine the impact of different measures of the president's agenda in response to research that uses 
more indiscriminate measures. The use of all televised speeches leans more toward this latter approach.

${ }^{4}$ The president's ability to set the agenda is modeled slightly different in Edward's work than others reviewed here. By using approval rating changes, Edwards looks more generally at public opinion response to the president, rather than examining public issue salience. Nevertheless, many of the speeches he looks at are specific policy proposals and whether the public responds positively to them, which is also an indicator of agendasetting ability.

${ }^{5}$ Aside from overall approval ratings, Edwards also examines public support for specific priorities in response to policy-specific speeches. Unfortunately, the public opinion data are not available for different issues in State of the Union Addresses in the earlier decades of this study. Additionally, the use of policy-specific speeches may evoke a different response from the public than a multi-policy speech such as the SUA. This is an avenue of possible future inquiry.

${ }^{6}$ As indicated in Appendix A, the mean number of sentences in the president's SUA dedicated to crime, education, and health and social welfare from 1954-2000 is 6, 10, and 24 , respectively.

${ }^{7}$ Other research explores the impact of the composition of Congress on the types of policy initiatives proposed on the president's agenda. In these cases, the president's agenda rather than the public's serves as the dependent variable. See for example, Eshbaugh-Soha (2005) and Peterson (1990).

${ }^{8}$ Appendix A displays descriptive statistics for all variables.

${ }^{9}$ The SUA is typically delivered in late January or early February. The post-speech polls range from about 1 month to about 8 months after the speech. However, this longer lag time is more the exception than the rule. Only 3 of the 47 polls were taken after May and these were in the earlier part of the time period: 1955, 1963, and 1968. These could have been expunged from the data, but I included them to encompass as many years as possible.

${ }^{10}$ For the Presidential Mentions, Congressional Attention, and Public Opinion variables, the data were categorized according to the following subjects: (1) Crime: criminal penalties, criminal procedure, child abuse, child pornography, death penalty, drug trafficking and enforcement, police protection; (2) Education: assessment testing, college aid and scholarships, library funding, National Science Foundation funding (NSF), teacher salaries, school aid, vocational education; (3) Health and social welfare: child care, child support, drug abuse, health research, highway safety, housing programs, prescription drugs, retirement, social security, unemployment programs, urban development, volunteerism/community service, worker safety. The Public Opinion data were compiled by the author from Gallup Public Opinion Polls available in the Lexus-Nexus database.

${ }^{11}$ In several instances, a substitute speech was used instead of the State of the Union Address. They are the following: 1969 - Plan for Domestic Legislation (Nixon); 1977 Economic Stimulus Proposal (Carter); 1981 - Economic Proposals Text (Reagan); 1989 - Budget Plan (Bush Sr.). This avoids the use of any speeches by lame-duck presidents. In 1993, President Clinton delivered what is sometimes referred to as an SUA despite his incoming status. The speech data are taken from the Congressional Quarterly Almanac.

${ }^{12}$ All data analysis was conducting using STATA 9.0.

${ }^{13}$ Durbin Watson h tests did not indicate autocorrelation problems in the crime and education models, as they did for the health and social welfare model. Thus, ordinary 
least squares (OLS) regression with robust standard errors was used to estimate the former two models.

\section{REFERENCES}

Bartels, Larry. 1991. Constituency Opinion and Congressional Policy Making: The Reagan Defense Buildup. American Political Science Review 85:457-476.

Baum, Matthew A., and Samuel Kernell. 1999. Has Cable Ended the Golden Age of Presidential Television? American Political Science Review 93:99-114.

Baumgartner, Frank R., and Bryan D. Jones. 1993. Agendas and Instability in American Politics. Chicago: University of Chicago Press.

Bond, J.R., and Richard Fleisher. 1990. The President in the Legislative Arena. Chicago: The University of Chicago Press.

Brace, Paul, and Barbara Hinckley. 1992. Follow the Leader. New York: Basic Books.

Canes-Wrone, Brandice, and Scott de Marchi. 2002. Presidential Approval and Legislative Success. The Journal of Politics 64:491-509.

Canes-Wrone, Brandice, and Kenneth W. Shotts. 2004. The Conditional Nature of Presidential Responsiveness to Public Opinion. American Journal of Political Science 48:690-706.

Ceaser, James W., Glenn E. Thurow, Jeffrey Tulis, and Joseph M. Bessette. 1981. The Rise of the Rhetorical Presidency. Presidential Studies Quarterly 11:158-171.

Cobb, Roger W., and Charles D. Elder. 1972. Participation in American Politics: The Dynamics of Agenda-Building. Baltimore: Johns Hopkins Press.

Cohen, Jeffrey E. 1993. The Dynamics and Interactions Between the President's and Public's Civil Rights Agendas: A Study in Leadership and Representation. Policy Studies Journal 21:514-522.

Cohen, Jeffrey E. 1995. Presidential Rhetoric and the Public Agenda. American Journal of Political Science 39:87-107.

Cohen, Jeffrey E. 1997. Presidential Responsiveness and Public Policy-making. Ann Arbor: The University of Michigan Press.

Covington, C.R., M.J. Wrighton, and R. Kinney. 1995. A 'Presidency-augmented' Model of Presidential Success on House Roll Call Votes. American Journal of Political Science 39:1001-1024.

Cunningham, Jennifer, and Michael K. Moore. 1997. Elite and Mass Foreign Policy Opinions: Who Is Leading This Parade? Social Science Quarterly 78:641-656.

Edwards, George. 2003. On Deaf Ears: The Limits of the Bully Pulpit. New Haven, CT: Yale University Press.

Edwards, George C., and Andrew Barrett. 2000. Presidential Agenda Setting in Congress. In Polarized Politics: Congress and the President in a Partisan Era, eds. Jon Bond \& Richard Fleisher. Washington DC: CQ Press.

Edwards, George C. III, and B. Dan Wood. 1999. Who Influences Whom? The President, Congress, and the Media. American Political Science Review 93:327-344.

Eshbaugh-Soha, Matthew. 2005. The Politics of Presidential Agendas. Political Research Quarterly 58:257-268.

Eshbaugh-Soha, Matthew, and Jeffrey Peake. 2004. Presidential Influence Over the Systemic Agenda. Congress and the Presidency 31:161-181.

Eshbaugh-Soha, Matthew, and Jeffrey Peake. 2005. Presidents and the Economic Agenda. Political Research Quarterly 58:127-138. 
Fiorina, Morris. 1996. Divided Government, 2nd ed. Needham Heights, MA: Allyn \& Bacon.

Flemming, Roy B., B. Dan Wood, and John Bohte. 1999. Attention to Issues in a System of Separated Powers: The Macrodynamics of American Policy Agendas. Journal of Politics 61:76-108.

Friedrich, Robert J. 1982. In Defense of Multiplicative Terms in Multiple Regression Equations. American Journal of Political Science 26:797-833.

Grusczynski, Lara. 2004. Who Listens When the President Speaks? The Role of the State of the Union in the Policy Process. Paper presented at the annual meeting of the Midwest Political Science Association, Chicago, IL.

Hill, Kim Q. 1998. The Policy Agendas of the President and the Mass Public: A Research Validation and Extension. American Journal of Political Science 42:1328-1334.

Hill, Kim Q., and Angela Hinton-Andersson. 1995. Pathways of Representation: A Causal Analysis of Public Opinion-Policy Linkages. American Journal of Political Science 39:924-935.

Iyengar, Shanto, and Donald Kinder. 1987. News that Matters Chicago: University of Chicago Press.

Kernell, Samuel. 1997. Going Public: New Strategies of Presidential Leadership. Washington DC: Congressional Quarterly Press.

Kingdon, John W. 1995. Agendas, Alternatives, and Public Policies, 2nd ed. New York: Harper Collins.

Light, Paul. 1991. The President's Agenda. Baltimore: Johns Hopkins University Press.

McCombs, Maxwell, and George Estrada. 1997. The News Media and the Pictures in Our Heads. In Do the Media Govern? Politicians, Voters, and Reporters in America, eds. Shanto Iyengar and Richard Reeves. Thousand Oaks, CA: Sage.

Miller, Warren E., and Donald E. Stokes. 1963. Constituency Influence in Congress. American Political Science Review 57:45-56.

Peake, Jeffrey. 2001. Presidential Agenda Setting in Foreign Policy. Political Research Quarterly 54:69-86.

Peterson, Mark A. 1990. Legislating Together: the White House and Capitol Hill from Eisenhower to Reagan. Cambridge, MA: Harvard University Press.

Ragsdale, Lyn. 1984. The Politics of Presidential Speechmaking, 1949-1980. American Political Science Review 78:971-984.

Rohde, David W., and Dennis M. Simon. 1985. Presidential Vetoes and Congressional Response: A Study of Institutional Conflict. American Journal of Political Science 29:397-427.

Stimson, James A., Michael B. MacKuen, and Robert S. Erikson. 1995. Dynamic Representation. American Political Science Review 89:543-65.

Sundquist, James. 1988. Needed: A Political Theory for the New Era of Coalition Government in the United States. Political Science Quarterly 103:613-635.

Wood, B. Dan, and Jeffrey S. Peake. 1998. The Dynamics of Foreign Policy Agenda Setting. American Political Science Review 92:173-184.

Yates, J., and A. Whitford. 2005. Institutional Foundations of the President's Issue Agenda. Political Research Quarterly 58:577-585.

Young, Garry, and William B. Perkins. 2005. Presidential Rhetoric, the Public Agenda, and the End of Presidential Television's 'Golden Age.' The Journal of Politics 67:1190-1205. 